\title{
Ethnobotanical Profiles and Phytochemical Constituents of Barringtonia racemosa L. for Potential Scrutiny of Bioactive Compounds through Plant Biotechnology
}

\author{
Nurul Izzati Osman ${ }^{1}$, Norrizah Jaafar Sidik ${ }^{1 *}$ and Asmah Awal ${ }^{2}$ \\ ${ }^{1}$ Faculty of Applied Sciences, Universiti Teknologi MARA, 40450 Shah Alam, Selangor, Malaysia. \\ ${ }^{2}$ Faculty of Plantation and Agrotechnology, Universiti Teknologi MARA, 40450 Shah Alam, Selangor, Malaysia.
}

\begin{abstract}
This paper reviews the traditional uses and customs of people in the use of Barringtonia racemosa L., a type of plant mangrove species in their daily life and medicinal approaches. In addition, the phytochemical constituents and the studies in plant biotechnology carried out on this species were also reviewed and summarized by referring to the available documented literatures. It is aimed to provide a systematic review of such topics to facilitate understanding and providing information regarding that particular species. From the current review of literature, it has been clearly depicted that $B$. racemosa is having promising potentials for natural product discovery through plant biotechnology to be further scrutinized in this species. The information gathered from the ethnobotanical uses of this species as well as its phytochemical constituents are useful to provide a significant background for future works regarding plant secondary metabolites from this species to be further explored by the application of plant biotechnology.
\end{abstract}

Keywords: Barringtonia racemosa L., Ethnobotany, Ethnopharmacology, Plant Bioactive Compounds, Phytochemistry

\section{Introduction}

Our mother nature has a great diversity of plant species and the existence of plant kingdom provides various benefits towards mankind. Plants may beneficially used for psychological, spiritual, cultural and medicinal elements ${ }^{1}$. Traditional uses of plants and its relationships with human are termed ethnobotany and are very well associated with cultural practice and belief. Indeed, the ethnobotanical approach which is based on the indigenous uses of plants has been the basis for modern scientific research in pharmacological studies and phytochemical screening. Furthermore, the usefulness of plants not only lies in its medicinal properties used in herbal treatment but in fact, plants have been among the most significant element in daily household needs and being incorporated in industrial setting for instance in the production of agrochemicals, flavours, colourants and fragrances due to the presence of bioactive compounds in plant species ${ }^{2}$.

Highly valued as a natural pharmaceuticallyimportant reservoir, plants are also known as an important source of industrially-valuable compounds due to plant bioactive constituents which are inherently exist in plant species. There are numerous studies have

\footnotetext{
*Author for correspondence

Email: nurulizzati70@gmail.com and norri536@salam.uitm.edu.my
} 
been documented so far reporting the importance of plant bioactive compounds in natural product discovery. However, productions of these compounds are critically affected by environmental factors such as climatic changes, nutrient availability, pathogenic threats and cultivation difficulties ${ }^{3}$. Therefore, in addition to the studies in the area of natural product chemistry, the application of plant biotechnology to produce bioactive agents by manipulating in vitro growth conditions and requirements has emerged as an exciting area of discovery. For instance, the research on cell suspension cultures establishment could be potentially used as a viable alternative to natural plant extraction and functions as a platform provider for high-value secondary metabolite production ${ }^{4}$.

One of the most widely distributed plant species with myriad functional uses is Barringtonia racemosa or commonly known as powder puff tree or fish poison tree. It is a type of mangrove species and has been used in various tribes around the world due to its wide geographical distribution from eastern Africa to northern Australia ${ }^{5}$. One of its well known functions is it could be used as fish poison and thus reflects its common name as the 'fish poison tree'. Since B. racemosa is widely distributed geographically, therefore it has so many vernacular names ${ }^{6}$ and being called differently in different regions of the world.

Ethnobotanically used as effective remedy for certain ailments, $B$. racemosa had been scientifically proven to have medicinal properties through various pharmacological activity studies as well. Previously, a record on $B$. racemosa pharmacological properties had been documented ${ }^{7}$ and the pharmacological effectiveness of this species therefore could serve as an important clue for further scrutiny of natural drug discovery of lead compounds to be carried out in this species. Even though B. racemosa had been used ethnobotanically in various tribes and had been proven to have significant pharmacological properties, however the existing literatures documenting plant biotechnology applications on B. racemosa are quite limited. Therefore, more studies could be possibly undertaken in this regard involving the applications of plant tissue culture.

The investigation pertaining to propagation potential through plant tissue culture had been documented in earlier reports ${ }^{8}$ through which the leaves were used as the explant to regenerate the production of in vitro plantlets. In addition to that, the plant biotechnology approach had been incorporated in a very few studies which include the establishment of callus culture and cell suspension culture of the species ${ }^{8-11}$. Due to the scarcity of investigations in plant biotechnology-related areas conducted on B. racemosa, therefore, there is a great potential for the species to be further studied in such a field.

This review was presented by fragmenting the information gathered on B. racemosa into ethnobotanical uses which encompassing its non-medicinal and medicinally-related uses respectively as well as its phytochemical constituents. The reviews compiled in this paper are meant to facilitate better understanding and to provide systematic documentation on ethnobotanical uses of this plant species and its phytochemical constituents.

\section{Botanical Description}

\subsection{Taxonomy and Nomenclature}

Barringtonia racemosa is one of the species in Plantae kingdom from genus Barringtonia which are classified under the family of Lecythidaceae. The Barringtonia genus got its name after Hon. Daines Barrington, 1727-1800, an English nobleman, lawyer, antiquary and naturalist who wrote a book on English trees ${ }^{5,12}$. Botanically, the 'racemosa' term at the later part of the scientific name are reflecting the racemes structure of the species that it possesses which depicts a stringlike arrangement of stalked flowers ${ }^{5}$. The taxonomic hierarchy of $B$. racemosa could be arranged in the following order ${ }^{13}$ :

- Kingdom: Plantae.

- Subkingdom: Viridiplantae.

- Infrakingdom: Streptophyta.

- Superdivision: Spermatophytina.

- Class: Magnoliopsida.

- Superorder: Asteranae.

- Order: Ericales.

- Family: Lecythidaceae.

- Genus: Barringtonia.

- Species: Barringtonia racemosa (L.). 


\subsection{Vernacular Names}

Owing to its widespread geographic distribution, the vernacular names of $B$. racemosa exist in various tribes and regions of the world. Different vernacular names are tabulated in Table 1.

\subsection{Botanical Features}

The trees of Barringtonia racemosa is a small to mediumsized evergreen shrub of around 4 to $8 \mathrm{~m}^{5}$ or occasionally large up to 20 to $27 \mathrm{~m}$ tall ${ }^{14}$ or even up to 30 to $47 \mathrm{~m}$ in height ${ }^{17}$. The bole may reach up to $50 \mathrm{~cm}^{14}$ to $100 \mathrm{~cm}$ in diameter and branch-less for up to $18 \mathrm{~m}^{17}$. Sometimes the bole having buttresses, smooth bark or fissured with grey or yellow hue. According to Orwa et al. ${ }^{5}$, no aboveground roots are present but they may have spreading surface roots. However, other record claimed that knee roots (pneumatophores) are sometimes present ${ }^{14}$.

Leaves of $B$. racemosa are alternate, crowded towards the ends of twigs, simple; with the stipules which are very small and caducous. The petioles are approximately up to $1.5 \mathrm{~cm}$ long, slightly winged with elliptical to obovate-oblong or oblanceolate blade of 5-42 cm $\times 2-16$ $\mathrm{cm}$ in size. The characteristic of leaf base is cuneate and narrowly tapering running into very short petiole, while the apex is deep green, acuminate, broadly tapering. The leaf appears to be entire to shallowly toothed or scalloped $\operatorname{margin}^{5,14}$.
Flowers of B. racemosa are attractive and fragrant with the colours of white to pale pink arranged in manyflowered pendulous sprays of up to $60 \mathrm{~cm}$ in length or even more, hanging on axillary infloresence ${ }^{5,17}$ as presented in Figure 1. The pendulous raceme could reach up to 70 to $100 \mathrm{~cm}$ long. Flowers are bisexual and sepals joined at the base, separating in 3-4 lobes. The flower petals are elliptic, up to $3 \times 1 \mathrm{~cm}$, attached to the staminal tube with numerous, long, white or pinkish stamens forming a large central mass of $3.5 \mathrm{~cm}$ in diameter. The ovary is 2 to 4 chambered and the style is red $^{5}$.

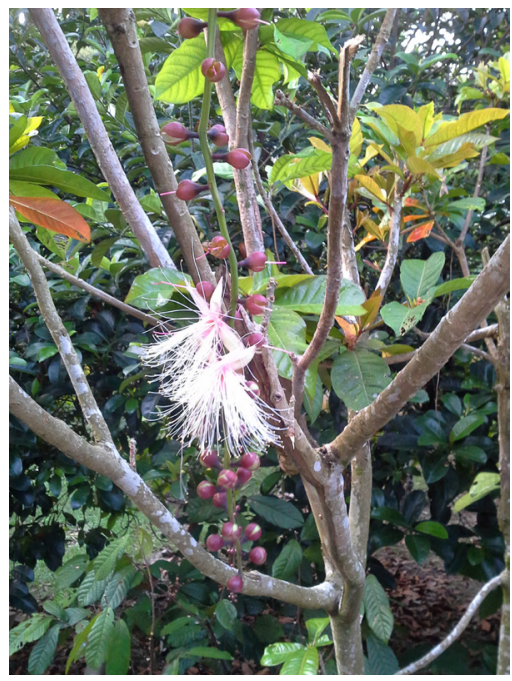

Fig. 1. Pinkish white flowers of B. racemosa are hanging on axillary infloresence.

Table 1: The vernacular names of B. racemosa according to geographical regions

\begin{tabular}{lll}
\hline Language/ Country / Region & Vernacular Name & Reference \\
\hline English & Barringtonia, brack-water mangrove, common putat, & 6,14 \\
Malaysia & hippo apple, powderpuff tree, wild guava. & \\
Brunei & Putat kampung, putat padi, putat darat, putat kedul. & 15,16 \\
Indonesia & Angas gimpalang, angas gimplang, putat aying. & 6,17 \\
Myanmar & Butun, alakan, butun darat, kungkungan, putat. & 6,17 \\
Cambodia & Kye-bin, kyi & 6 \\
Philippines & Dawm trojiekbres, pchek tekbray & 6 \\
& Botong, ulam, kasouai, putat, tuba-tuba, kutkut-timbalon, & 6,17 \\
Thailand & nuling,paling & 17 \\
Laos & Chik & 6 \\
Papua New Guinea & Som pawng & 6 \\
China & Paniak, paopao & 6 \\
India & Yu rui & 15 \\
East Africa & Samudrapandu & 6 \\
Southern Africa & Mtomondo & 6 \\
Tanzania & Poeierkwasboom, iBhoqo, iBoqo (Zulu) & 6 \\
Madagascar & Mkuvumkuvu, mtomondo & 6 \\
\hline
\end{tabular}


The distinctive features of the fruit are presented as having conical to ovate chicken egg-sized of about 3 to 9 $\mathrm{cm} \times 2$ to $5.5 \mathrm{~cm}$ (Figure 2) and crowned by the remains of the persistent calyx. The style is fleshy at first and turns hard, fibrous and yellowish-brown as maturity is attained. The fruits are green with purple and dark red tinge and usually one-seeded. The seed lies in the inner part of the fruit with the size of approximately 2 to $4 \mathrm{~cm}$ $\mathrm{x} 1$ to $2.5 \mathrm{~cm}^{5,14}$.

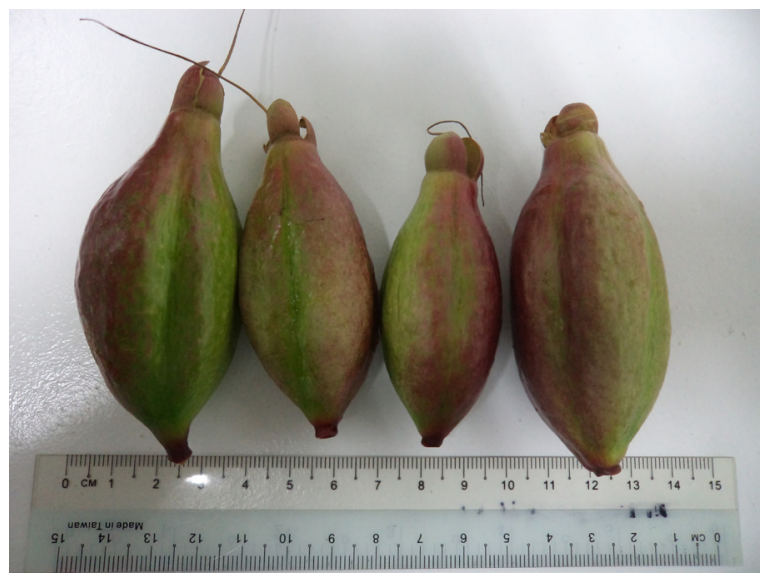

Fig. 2. Fruits of B. racemosa which are green with purple and dark red tinge.

\subsection{Geographical Distribution and Ecology}

The Barringtonia genus comprises about 40 to 50 species worldwide. South-East Asia especially the Malesian region is the centre of diversity in which there are approximately 30 to 40 species could be found in the region ${ }^{14,17}$. The species of Barringtonia racemosa is distributed from eastern Africa and Madagascar to Sri Lanka, India, Myanmar, southern China, Taiwan, the Ryukyu Islands (Japan), Thailand, the Andaman and Nicobar Islands (India), throughout the Malesian region towards Micronesia, Polynesia (east to Fiji and Samoa) and northern Australia ${ }^{5}$. Well known as a mangrove species, $B$. racemosa grows well in tropical and subtropical regions in primary and secondary forest, mostly restricted to inundated flood plains on tidal river banks, or in less saline swampy areas ${ }^{14,15}$. Although being well recognised as mangrove associate, this plant species can also be found in tropical rainforest, open lowlands and thickets ${ }^{5}$. Nevertheless, it cannot tolerate even light frost and thus can only grow in wet and moist tropical and subtropical climates ${ }^{5}$ at the height of 500 900 m altitude ${ }^{14}$.

\section{Ethnobotanical Profiles}

\subsection{Construction}

The bole and wood from $B$. racemosa had been widely used for construction purposes. It has been documented that the wood derived from this species are used in local house building, general planking, flooring and mouldings ${ }^{17}$. In addition, they are also useful in light and temporary construction and used to produce veneer and plywood to form a layer of decorative lining of fine wood to cover the coarse surfaces in construction ${ }^{14}$. Due to these properties, its uses in constructive fabrication and furnishing have been extended to produce household utensils and included as an element in interior finishing and in the manufacturing of wooden pallets.

Apart from that, it is also suitable to be used for carving and turnery owing to the properties of the wood which is light and soft yet moderately resistant to pressure impregnation. In Nicobar Island, New Guinea and Pacific islands, the bole of $B$. racemosa had been utilized in the manufacturing of canoe ${ }^{17}$. Meanwhile, in South India, the durable characteristic of the wood makes it suitable to be used in cabinet making, boat building, carts and rice pounders ${ }^{18}$. The bark of $B$. racemosa had been recorded to be used as a source of fibre and hence suitably used as tying materials. Upon being treated with preservatives, the timber of $B$. racemosa serves as a suitable candidate to make good ties and paving blocks in Philippines ${ }^{5}$.

\subsection{Animal Poisons}

Being commonly named as fish-poison tree, fish-killer tree and fish-poison wood, it is called as such due to its potential in poisoning fish ${ }^{19,20}$. It is used to stun fishes and octopus in the area of Pacific islands ${ }^{21}$ and many regions of the world where the species are native to. When the pounded materials of $B$. racemosa passes through the gills of fish or being directly ingested, the fishes are therefore stunned. The grated and pounded parts of $B$. racemosa are introduced into stagnant pool or slow-flowing stream and with that, the poisons are concentrated and not easily being washed away by the water current. The uses of this species as animal poisons are attributed to its tannin and saponin content ${ }^{20}$. In stunning fishes, the saponins from B. racemosa are taken 
in directly into bloodstream through gills. Even though the saponins effects are powerful, the results on fishes are not fatal. In addition, the toxins which act on fishes' respiratory organs are not affecting their edibility. $B$. racemosa and other species of Barringtonia genus are widely used for this purpose and most frequently, the seeds $^{21}$ and leaves parts are being used ${ }^{22}$ in addition to bark and fruits ${ }^{20}$.

Apart from effectively used as fish poison, the species is also used to poison wild pigs in Philippines ${ }^{17}$. The effectiveness of this species to poison animals had alsobeen verified scientifically. The toxicity of $B$. racemosa extract had been proven to be useful in combating agricultural pest threats. It had been proven that this species exerted toxic effects against golden apple snail by using the seed kernel $^{23}$. In addition to that, the ethnobotanical records of this plant species in Palawan Island, Philippines had shown that it is used as insecticide ${ }^{24}$. B. racemosa was reported to have insecticide potential against citrus aphids ${ }^{14}$. For instance in certain district of Bangladesh, it is used as insect repellent ${ }^{25}$ and snake repellent ${ }^{26,27}$. Besides, the potency of this species to produce toxic effects towards mosquitoes, snails and brine-shrimp had been documented as well ${ }^{28}$. Interestingly, scientific studies had proven that fruit and seed extracts of this mangrove species are having molluscicidal, cercariacidal, larvicidal, antiplasmodial ${ }^{29,30}$ and piscicidal properties ${ }^{29}$. The possible role of $B$. racemosa to control snail intermediate hosts of schistosomiasis and dengue fever had been proven by Adewunmi et al., ${ }^{29}$ in a research conducted on Biomphalaria glabrata snails and Aedes aegypti. In such assay, the pericarp extracts were more potent in molluscidal activities than those of seed extracts while the seed extracts had shown promising larvicidal activities.

\subsection{Culinary}

The shoots and young fruits are usually eaten raw and mostly favoured by the elderly. The young fruits are consumed and favoured due to its crunchy texture ${ }^{31}$. Its leaves are usually served as salad ${ }^{32}$ especially in Malay custom and eaten together with shrimp paste ${ }^{31}$ in main meals of lunch and dinner. Additionally, it is also being added in Malay's cooking as sauté paste ${ }^{31}$. In certain region of the world, its use as an element in culinary is also manifested in which the seeds are milled to produce edible flour. They are pounded to extract the starchy content whereby the pounded seeds are used to make foods such as cakes ${ }^{5,14}$.

\subsection{Household and Other Daily Uses}

According to Kitalong et al., ${ }^{33}$ B. racemosa is used for cleaning purpose of personal hygiene such as soap by the people of Republic of Palau. The suitability of $B$. racemosa to be used as soap might be owing to its saponin content whereby the presence of saponin in this plant species had been identified and validated by a number of previous studies ${ }^{23,34}$. The presence of saponin is useful in soap making since saponin has been recognized to be able to exhibit distinct foaming properties and feasible to be added to shampoos, liquid detergents, toothpastes as emulsifier and long-lasting foaming agent ${ }^{35,36}$.

Other than being used as cleaning agent, the pulp of B. racemosa is used in paper industry ${ }^{14}$. This species is also used as a good source of dye which produces reddish brown dye due to its tannin content which has been associated to its bark of stems and roots. The tannins found in the species belong to the group of condensed proanthocyanidins which produce reddish leather and used to dye vegetable fibres.

In addition, the wood of this plant species is used as a source of fuel and firewood ${ }^{14}$. It had been reported that oil from the seeds is used for lighting ${ }^{37}$. Apart from being plucked and extracted for multiple ethnobotanical purposes, this species also being appreciated as ornamental plant species and planted for decorative purposes $^{5,14,17}$ which might be due to its attractive characteristics of delicate white flowers with masses of pinkish white stamens and its unique hanging fruits found on the hanging racemes.

\subsection{Ethnopharmacological Uses}

Ethnopharmacological term is used to refer to the traditional uses of plant species specifically for medicinal purposes. Barringtonia racemosa $L$. has been traditionally used in various tribes around the world as a type of medicinal approaches. The ethnomedicinal properties of the species according to the related areas and ethnicity were presented in Table 2. 
Ethnobotanical Profiles and Phytochemical Constituents of Barringtonia racemosa L. for Potential Scrutiny of Bioactive Compounds through Plant Biotechnology

Table 2: Ethnopharmacological uses of B. racemosa in various regions of the world

\begin{tabular}{|c|c|c|c|}
\hline Ethnomedicinal properties & $\begin{array}{l}\text { Area of use /Ethnic } \\
\text { involved }\end{array}$ & Parts used / Method of Application & References \\
\hline $\begin{array}{l}\text { Used as deobstruent, in the } \\
\text { treatment of cough, asthma and } \\
\text { diarrhoea. Also applied for skin } \\
\text { diseases, colic and parturition }\end{array}$ & Sri Lanka & $\begin{array}{l}\text { The fruits are used for the treatment of cough, } \\
\text { asthma and diarrhoea. It is powdered to be used } \\
\text { in skin diseases. The aromatic seeds are used in } \\
\text { colic and parturition. }\end{array}$ & 38 \\
\hline Treatment of otitis media & Palau, Micronesia & $\begin{array}{l}\text { Young leaves are crushed to produce herbal } \\
\text { mixtures and injected into the ears of patients. }\end{array}$ & 39 \\
\hline Treatment of hallucination & $\begin{array}{l}\text { Eastern part of former } \\
\text { Zaire by Nyindu people }\end{array}$ & $\begin{array}{l}\text { The pounded bark is soaked in water and the } \\
\text { solution is used to wash patient's head. }\end{array}$ & 40 \\
\hline $\begin{array}{l}\text { Treatment of hypertension, } \\
\text { itchiness and chicken pox }\end{array}$ & Malaysia & $\begin{array}{l}\text { Its leaves are used to reduce high blood } \\
\text { pressure and used as a depurative, in which the } \\
\text { pounded leaves, roots and barks are used to } \\
\text { reduce itchiness and chicken pox. }\end{array}$ & 5,41 \\
\hline $\begin{array}{l}\text { Treatment of cancer-like diseases, } \\
\text { jaundice, dog-bite wounds }\end{array}$ & Kerala, India & Not specified & 42 \\
\hline $\begin{array}{l}\text { Treatment of malaria, cough, } \\
\text { asthma, diarrhoea, eye } \\
\text { inflammation, sores, rheumatism, } \\
\text { fever and used for women in } \\
\text { parturition }\end{array}$ & $\begin{array}{l}\text { Africa } \\
\text { (South Africa, Eastern } \\
\text { Africa) }\end{array}$ & $\begin{array}{l}\text { The Zulus use the fruit to treat malaria while } \\
\text { the pulverized fruit is used as snuff. Seeds are } \\
\text { used for the treatment of eye inflammation. } \\
\text { Meanwhile, midwives use them for parturition. } \\
\text { Bark decoction is applied externally for } \\
\text { rheumatism treatment. Root decoction is used } \\
\text { as febrifuge. }\end{array}$ & 5,14 \\
\hline Treatment of snake bite & $\begin{array}{l}\text { Bagerhat district and } \\
\text { Balidha village, Jessore } \\
\text { district, Bangladesh by } \\
\text { kavirajes }\end{array}$ & $\begin{array}{l}\text { Leaves are used as a snake repellent and in } \\
\text { Jessore and Bagerhat districts of Bangladesh, } \\
\text { the leaves are smashed and the decoction is } \\
\text { orally consumed for snake bite treatment. }\end{array}$ & $26-27,43$ \\
\hline $\begin{array}{l}\text { Treatment of heartburn, bleeding } \\
\text { and abortion }\end{array}$ & $\begin{array}{l}\text { Palauan archipelago, } \\
\text { Western Micronesia } \\
\end{array}$ & Not specified & 33 \\
\hline Treatment of cough & Buton, Indonesia & Not specified & 44 \\
\hline $\begin{array}{l}\text { Used as anti-diabetic, anti- } \\
\text { malaria, antidote }\end{array}$ & Tamil Nadu, India & Seed is used for the therapeutic purposes & 45 \\
\hline $\begin{array}{l}\text { Treatment of cough, asthma, } \\
\text { diarrhoea, stomachache, } \\
\text { ophtalmia and jaundice }\end{array}$ & Uttara Kannada, India & $\begin{array}{l}\text { Aromatic seeds used in stomach ache and } \\
\text { ophthalmia; seed kernel with milk for treating } \\
\text { jaundice. Also used in the preparation of skin } \\
\text { ointment. }\end{array}$ & 46 \\
\hline $\begin{array}{l}\text { Treatment of scabies, tetanus } \\
\text { and for placental apposition in } \\
\text { women }\end{array}$ & $\begin{array}{l}\text { Southeastern } \\
\text { Madagascar }\end{array}$ & $\begin{array}{l}\text { Leaves are used for scabies, tetanus and } \\
\text { placental apposition. }\end{array}$ & 47 \\
\hline $\begin{array}{l}\text { Treatment of pain, joint pain and } \\
\text { bone fracture }\end{array}$ & Kagrachari, Bangladesh & $\begin{array}{l}\text { Murong tribes use the leaves to be applied } \\
\text { externally. }\end{array}$ & 48 \\
\hline $\begin{array}{l}\text { Treatment of body ache, fever, } \\
\text { joint pain, snake bite }\end{array}$ & $\begin{array}{l}\text { Nancowry group of } \\
\text { islands (Andaman and } \\
\text { Nicobar Island) by } \\
\text { Nicobarese }\end{array}$ & Applied topically to the affected area & 49 \\
\hline Treatment of snake poisoning & Songkhla, Thailand & The root is prepared to make decoction & 50 \\
\hline
\end{tabular}




\section{Phytochemical Constituents}

\subsection{Terpenoids}

Terpenoid metabolites are one of the largest and most diverse classes of chemical compounds derived from plants. Plants use terpenoids for both basic functions in growth and development as well as for more specialized plants chemical interactions and protection ${ }^{51}$. For instance, monoterpenes and diterpenes generally act as allelopathic agents, attractants in plant-plant or plantpathogen/herbivore interactions or repellants ${ }^{52}$. Through scientific discoveries, a great number of terpenoid metabolites had been isolated as phytochemical constituents in B. racemosa.

Saponins for instance are classified as triterpene glycosides which are very well known to be inherently present in B. racemosa. The presence of such compounds had been acknowledged to be the reason of its suitability to be used as cleaning agents due to its surface-active properties $^{35,53}$ and may produce long-lasting foam ${ }^{36}$. In addition, saponins in $B$. racemosa serve as the key factor of its insecticidal and piscicidal activities to stun fish and to stupefy animals and pests. Biologically, the mechanism by which saponins exert its toxicity as animal poison could be understood by the occurrence of hemolysis that they cause. When saponins are in the proximity of animal cell membrane, their interaction with cholesterol may create pores and resulting in hemolysis. The effects of hypersecretion due to such interaction will eventually cause toxicity to the fishes being stunned ${ }^{54}$.

To date, several types of saponins had been identified from $B$. racemosa extract which are baringtonin and sapogenins. Three different metabolites had been further isolated from triterpenoid sapogenins group which are R1-barringenol, barringtogenol ${ }^{55,56}$ and barringtogenic acid $^{55}$. Other two new triterpenoids had been successfully isolated in which the presence of olean-18en-3beta-O-E-coumaroyl ester and olean-18-en-3beta$\mathrm{O}$-Z-coumaroyl ester from stem bark of $B$. racemosa had been discovered along with five known compounds which were germanicol, germanicone, betulinic acid, lupeol and taraxerol ${ }^{57}$.

In year 2000, a research had been documented ${ }^{58}$ which reported the presence of two novel neoclerodane type diterpenoids which were methyl-15, 16-epoxy-12-oxo-3,13(16), 14-neo-clerodatrien-18, 19-olide-17-carboxylate (nasimalun A) and dimethyl15,16-epoxy-3, 13(16), 14-neo-clerodatrien-17, 18-dicarboxylate (17-carboxymethylhardwickiic acid methyl ester (nasimalun B). First documentation on the presence of bartogenic acid had been recorded by Sun et al., ${ }^{59}$ from the extract of stem bark. In 2008, NurulMaryam et al., ${ }^{60}$ reported that great amount of $\beta$-carotene and lycopene were found in the ethanolic extract of B. racemosa leaf. Later on, further studies had been published which verified the presence of bartogenic acid done by Patil et al ${ }^{61}$. In such discovery, they confirmed the isolation of bartogenic acid from the fruits of this plant species. A terpene compound classified under tetraterpenoid had been studied by Behbahani et al., ${ }^{9}$ and her findings verified the presence lycopene in callus and cell suspension cultures of $B$. racemosa.

\subsection{Plant Sterols}

Plant sterols are the components occur in plant cells which are generally functions to control membrane fluidity and permeability. The presence of sterol in plants is associated with a number of benefits for instance it has the potential to be used as natural preventive dietary product in lowering plasma cholesterol level ${ }^{62}$. Phytosterols had been proven to play a key role in plant innate immunity against bacterial pathogens as well ${ }^{63}$. In addition, they also have functions in temperature adaptation of plants. Considered as membrane reinforces which sustain the domain structures of cell membrane, plant sterols also involve in embryonic growth of plants and in fundamental biological process ${ }^{64}$. In B. racemosa, the presence of stigmasterol had been isolated and identified from the ethyl acetate extract of stem bark. The isolation was done by using Silica Sephadex LH20 column chromatography and identified by NMR analysis $^{59}$.

\subsection{Phenolics}

Phenolics are compounds possessing one or more aromatic rings with one or more hydroxyl groups. They are broadly diversified ranging from simple molecules to highly polymerized substances with more than 8000 compounds being categorized into the group. Plant phenolics can be further classified into several subgroups which are phenolic acids, flavonoids, tannins 
(non-flavonoid polyphenols), stilbenes and lignans ${ }^{65}$. Phenolic compounds are frequently associated with antioxidative properties and being recognized as natural antioxidants.

Phenolic acids are the hydroxy derivatives of cinnamic acid or hydroxy derivatives of benzoic acid ${ }^{66}$. Several phenolic acids had been identified in B. racemosa extracts. A compound identified as 3',3'-dimethoxy ellagic acid had been discovered from the ethyl acetate extract of $B$. racemosa's stem bark ${ }^{59}$. From the phytochemical constituent analysis in this species, the findings revealed that the water extract of shoots contained three phenolic acids which were gallic acid, ellagic acid and protocatechuic acid ${ }^{32}$.

As a large group of polyphenols, flavonoids are important naturally occurring plant products which can be ubiquitously found in all families of plant kingdom. They are chemically characterized by having multiple phenol structural units. Flavonoid compounds can further be classified into five major subgroups which are flavanones, flavones, flavonols, flavanols (catechins) and isoflavones. In addition, proanthocyanidins and anthocyanins are also known as subgroups of flavonoid compounds ${ }^{66}$. The presence of total phenolic content and total flavonoid content in the extracts of aerial parts of the species had been verified as well ${ }^{60}$. This was further seconded by later findings by Amran et al., ${ }^{67}$ in which they found there were high total phenolic and total flavonoid contents in the fruits of $B$. racemosa. Upon phytochemical analysis done on water extract of $B$. racemosa, the shoots of this species were found to posses three flavonoid compounds which were quercetin, rutin and kaempferol ${ }^{32}$ whereby it has been acknowledged that quercetin and kaempferol are the two most predominating flavonols found in fruits and vegetables.

Tannin is another group of plant polyphenolic compounds under the phenolic groups which are characterized by having polymerized structure. The term 'tannin' comes from French word which reflects the tanning properties of this species ${ }^{68}$. To date, very little is known about the validated composition of tannin in $B$. racemosa and no data on structural elucidation of the compounds have ever been reported. However, the total tannin content of the bark has been estimated to be $18 \%$ which belongs to the group of condensed proanthocyanidins and contributes to its reddish brown dye production ${ }^{14}$.

\section{Application of Plant Biotechnology in B. racemosa}

Plant biotechnology offers advantageous alternative to the conventional breeding methods in the propagation of plant. In addition, plant biotechnology can also be utilized in the in vitro production of important plant secondary metabolites. The application of plant tissue culture as one of the pertinent elements in plant biotechnology could confer benefits owing to the totipotency property of plants. Totipotency is a special characteristic possessed by cells in young tissues and meristems ${ }^{69}$. By adopting the practises of plant tissue culture, total genetic potential of the parent plant could be maintained through totipotency. The adoption of micropropagation technology through plant tissue culture method has broadened the potential of greater plant production of selected traits rapidly which can overcome the slow and labour-intensive process with the advantages of season-independent plant breeding ${ }^{70}$.

Nevertheless, the application of plant biotechnology especially in the adoption of plant tissue culture in B. racemosa are still very few. The regeneration of this species through plant tissue culture was only recorded in a study published in 2007 whereby they managed to establish a protocol for in vitro propagation of $B$. racemosa from leaf explant ${ }^{8}$. They found that the leaf explants which were cultured on Woody Plant Medium (WPM) supplemented with $30 \mathrm{~g} / \mathrm{l}$ sucrose and treated with $2 \mathrm{mg} / \mathrm{l}$ kinetin and $0.2 \mathrm{mg} / \mathrm{l} \mathrm{IBA}$ had successfully induced optimum shooting response. Meanwhile, the supplementation of $3 \mathrm{~g} / \mathrm{l}$ activated charcoal and 0.8 $\mathrm{mg} / \mathrm{l}$ IBA had been used as a good rooting induction medium in this species. Excellently acclimatized, the in vitro plantlets of $B$. racemosa were survived after being transferred to mixed soil and were grown well in the glass house.

Meanwhile, the effort in establishing callus culture in $B$. racemosa was previously recorded in a number of studies. The earliest documented protocol for the establishment of callus culture was made in 2011. In such experiment, the researchers found that the fast growing and friable calli formation were initiated in the culture of leaf explant treated with $2.0 \mathrm{mg} / \mathrm{l} 2,4-\mathrm{D}$ in WPM medium ${ }^{9}$. Later on, in 2013 another research had been documented in describing the protocol of callus culture establishment from leaf and endosperm explants 
of $B$. racemosa $a^{10}$. Upon callus induction percentage assessment, the highest record was identified in the culture of endosperm explant treated with $1.5 \mathrm{mg} / \mathrm{l} 2,4$ $\mathrm{D}$ and $0.5 \mathrm{mg} / \mathrm{l}$ kinetin in Murashige and Skoog's (MS) medium whereby the calli formed from such treatment were found to be friable and grew intensively. In the most recent study of callus culture establishment which was published in 2016, the endosperm explant of $B$. racemosa was proven to be productive in yielding callus with desirable friable morphology ${ }^{11}$. However, the optimal combination of Plant Growth Regulators (PGR) was different as compared to the previously documented research whereby the latter found that $1.0 \mathrm{mg} / \mathrm{l} 2,4$ $\mathrm{D}$ in the presence of $1.5 \mathrm{mg} / \mathrm{l}$ kinetin was the optimal treatment for callus induction.

Research in the area of plant biotechnology which involves the establishment of cell suspension culture and secondary metabolite analysis was extremely limited and only found in a study documented in 2011. In such a study, they established optimum cell suspension culture by using friable calli cultured in liquid B5 medium. Further, they determined the content of lycopene in the cultures by chromatographic analysis. The effect of light towards lycopene level was investigated and it had been determined that the accumulation of lycopene in cell suspension culture was higher in the presence of light than in the darkness.

Due to the rarity of the research in the area of plant biotechnology conducted in this mangrove species, especially in the efforts of producing as well as enhancing its phytochemical constituents, therefore there's tremendous potential for further investigation to be carried out in B. racemosa. The involvement of intense studies in such particular area for instance through the application of plant tissue culture, mass production through bioreactor as well as enhancement of phytochemical compounds through the action of elicitor could be made possible by harnessing the resources and competency in plant biotechnology.

\section{Conclusion}

Considering the usefulness of this plant species and its versatile functions in human lives, $B$. racemosa is indeed having great potentials to be further scrutinized owing to its bioactive compounds. With respect to its phytoconstituents, the discovery pertaining to the compounds present in the species could be further explored to produce fruitful productions of not only medicinally important compounds, but also those with tanning and colouring properties. Due to the scantiness of research in the area of plant biotechnology in this species, hence the research in the respective area on $B$. racemosa should be intensified and diversified to ensure the benefits of $B$. racemosa could be fully harnessed through further exploratory investigations.

\section{Acknowledgement}

The authors would like to acknowledge the financial support provided by Institute of Research Management and Innovation (IRMI) of Universiti Teknologi MARA through Geran Inisiatif Penyeliaan (GIP) with the grant code number of 600-IRMI/GIP 5/3 (0024/2016).

\section{References}

1. Sakurada T, Mizoguchi H, Katsuyama S, Komatsu T, Kuwahata H, Rombolà L, et al. Ethnopharmacological approaches used to identify medicinal plants. In: Bagetta C, Cosentino M, Corasaniti MT, Skurada S, editors. Herbal medicines: Development and validation of plantderived medicines for human health. Boca Raton: CRC Press Taylor and Francis Group; 2012. p. 27-49.

2. Aijaz A, Jain S, Hariharan AG. Effect of elicitation on the production of phyto-constituents through plant tissue culture techique- A review. Int J Drug Discovery Herb Res. 2011; 1(2):84-90.

3. Vannini C, Campa M, Sassi F, Bracale M. Medicinal plants: Molecular biology/biotechnology approach. In: Bagetta C, Cosentino M, Corasaniti MT, Skurada S, editors. Herbal medicines: Development and validation of plant-derived medicines for human health. Boca Raton: CRC Press Taylor and Francis Group; 2012. p. 51-77.

4. Moscatiello R, Baldan B, Navazio L. Plant cell suspension cultures. Methods Mol Biol. 2013; 953:77-93. https://doi. org/10.1007/978-1-62703-152-3_5

5. Orwa C, Mutua A, Kindt R, Jamnadass R, Simons A. Agroforestree Database: A tree reference and selection guide version 4.0; 2009. Available from: http://www. worldagroforestry.org/sites/treedbs/treedatabases.asp

6. Quattrocchi U. CRC World Dictionary of medicinal and poisonous plants: Common names, scientific names, eponyms, synonyms and etymology. Boca Raton: CRC 
Ethnobotanical Profiles and Phytochemical Constituents of Barringtonia racemosa L. for Potential Scrutiny of Bioactive Compounds through Plant Biotechnology

Press Taylor and Francis Group; 2012. p. 542. https://doi. org/10.1201/b16504

7. Osman NI, Norrizah JS, Awal A. Pharmacological activities of Barringtonia racemosa L. (Putat), a tropical medicinal plant species. J Pharm Sci Res. 2015; 7(4):185-8.

8. Behbahani M, Ali AM, Muse R. Plant regenerations from leaf explants of Barringtonia racemosa. J Med Plant Res. 2007; 103-8.

9. Behbahani M, Shanehsazzadeh M, Hessami MJ. Optimization of callus and cell suspension cultures of Barringtonia racmosa (Lecythidaceae family) for lycopene production. Sci Agric (Piracicaba, Braz). 2011; 68(1):6976. https://doi.org/10.1590/S0103-90162011000100011

10. Dalila DZ, Jaafar H, Manaf AA. Effects of 2,4-D and kinetin on callus induction of Barringtonia racemosa leaf and endosperm explants in different types of basal media. Asian J Plant Sci. 2013; 12(1):21-7. https://doi. org/10.3923/ajps.2013.21.27

11. Osman NI, Norrizah JS, Awal A. Effects of variations in culture media and hormonal treatments upon callus induction potential in endosperm explant of Barringtonia racemosa L. Asian Pac J Trop Biomed. 2016; 6(2):143-7. https://doi.org/10.1016/j.apjtb.2015.10.007

12. Nicholson G. Encyclopaedia of plants. Delhi, India: Anmol Publications; 1991. p.159.

13. Integrated Taxonomic Information System. Barringtonia racemosa L. (Spreng); 2016. Available from: http:// www.itis.gov/servlet/SingleRpt/SingleRpt?search topic $=$ TSN\&search_value $=896469$

14. Kaume RN. Barringtonia racemosa (L.) Spreng. In: Jansen PCM, Cardon D, editors. PROTA (Plant Resources of Tropical Africa/Ressources végétales de l'Afrique tropicale); Netherlands. 2005. p. 37-39.

15. Koh HL, Chua TK, Tan CH. A guide to medicinal plants: An illustrated, scientific and medicinal approach. Singapore: World Scientific Publishing Co. Pte. Ltd; 2009. p. 26-27. https://doi.org/10.1142/9789812837103

16. Herbal Medicine Research Centre, Institute for Medical Research. Compendium of Medicinal Plants Used in Malaysia. Kuala Lumpur: HMRC IMR; 2002. p.102.

17. Yaplito MA. Barringtonia J.R. In: Forster, Forster JG, Valkenburg JLCH, Bunyapraphatsara N, editors. Plant Resources of South-East Asia No. 12(2): Medicinal and poisonous plants 2. Netherlands: Backhuys Publisher; 2001. p. 101-7.

18. Asouti E, Fuller DQ. Trees and woodlands of South India archaeological perspectives. Walnut Creek, California USA: Left Coast Press; 2007.
19. Neuwinger HD. African ethnobotany poisons and drugs. Heidelberg, Germany: Chapman \& Hall; 1996. p. 899.

20. Williams CJ. Medicinal plants in Australia Volume 3: Plants, potions and poisons. NSW Australia: Rosenberg Publishing; 2012. p. 265. PMid:25215075 PMCid:PMC4129810

21. Etoh T. Edible plants and poisonous plants in Micronesia. (1) Poisonous plants in Yap. Kagoshima University Research Center for the Pacific Islands, Occasional papers. 2001; 34: 141-4.

22. Kritzon C. Fishing with poisons; 2003. Available from: http://www.primitiveways.com/fish_poison.html

23. Musman M. Toxicity of Barringtonia racemosa (L.) kernel extract on Pomacea canaliculata (Ampullariidae). Trop Life Sci Res. 2010; 21(2):41-50. PMid:24575198 PMCid:PMC3819080

24. Sopsop LB, Buot IE. The importance of non-wood forest products in the household economy of the direct users of aborlan guba system, Palawan Island, Philippines. J Environ Sci Manag. 2011; 14(2):50-9.

25. Mollik MAH, Hossan MS, Paul AK, Taufiq-Ur-Rahman M, Jahan R, Rahmatullah M. A comparative analysis of medicinal plants used by folks medicinal healers in three districts of Bangladesh and inquiry as to mode of selection of medicinal plants. Ethnobot Res Appl. 2010; 8:195-218. https://doi.org/10.17348/era.8.0.195-218

26. Dey A, De JN. Traditional use of plants against sankebite in Indian subcontinent: A review of the recent literature. Afr J Tradit Complement Altern Med.2012; 9(1):153-74.

27. Rahmatullah M, Hasan MM, Ahmed M, Khan MW, Hossan MS, Rahman MM, Nasrin D, Miajee ZUMEU, Hossain MS, Jahan R, Khatun MAA. Survey of medicinal plants used by folk medicinal practitioners in Balidha village of Jessore District, Bangladesh. Am-Eurasian J Sustain Agric. 2010; 4(2),111-6.

28. Hutchings A, Scott AH, Lewis G, Cunningham A. Zulu medicinal plants- an inventory. South Africa: University of Natal Press; 1996. p. 212.

29. Adewunmi CO, Aladesanmi AJ, Adewoyin FB, Ojewole JAO, Naido N. Molluscidal, insecticidal and piscicidal activities of Barringtonia racemosa. Nig J Nat Prod and Med. 2001; 5:56-8. https://doi.org/10.4314/njnpm. v5i1.11727

30. Ojewole JAO, Nirasha ON, Adewunmi CO. Molluscicidal, cercariacidal, larvicidal and antiplasmodial properties of Barringtonia racemosa fruit and seed extracts. Bull Lat Am Carribean Med Aromat Plants. 2004; 3(5):88-92. 
31. Rukayah A. Ulam dan sayuran tempatan Semenanjung Malaysia. Kuala Lumpur: Dewan Bahasa dan Pustaka; 2009. p. 109-12.

32. Kong KW, Sarni MJ, Ismail A, Aminudin N, Abdul-Aziz A. Polyphenols in Barringtonia racemosa and their protection against oxidation of LDL, serum and haemoglobin. Food Chem. 2014; 1(146):85-93. https://doi.org/10.1016/j. foodchem.2013.09.012 PMid:24176317

33. Kitalong AN, Balick MJ, Rehuher F, Besebes M, Hanser S, Soaladaob K et al. In: Liston J, Clark G, Alexander $\mathrm{D}$, editors. Plants, people and culture in the villages of Oikull and Ibobang, Republic of Palau. Pacific Island heritage: Archaeology, identity and community. Canberra. Australia: Anu E Press; 2011. p. 63-84.

34. Lahiri JK, Ghosh S. Chemical examination of the seeds of Barringtonia acutangula.Gaertn J Am Pharm Assoc. 1942; 7:193-4. https://doi.org/10.1002/jps.3030310701

35. Chen, YF, Yang CH, Chang MS, Ciou, YP, Huang YC. Foam properties and detergent abilities of the saponins from Camellia oleifera. Int J Mol Sci. 2010; 11:4417-25. https://doi.org/10.3390/ijms11114417 PMid:21151446 PMCid:PMC3000090

36. Tanaka O, Tamura Y, Masuda H, Mizutani K. In: Waller GR, Yamasaki K, editors. Saponins used in food and agriculture. New York, NY, USA: Plenum Press; 1996. p. 1-11. https://doi.org/10.1007/978-1-4613-0413-5_1

37. Usher G. A dictionary of plants used by man. Delhi, India: CBS Publishers and Distributors; 1984. p. 79-80.

38. Jayaweera DMA. Medicinal plants. III. National Science Council of Sri Lanka; 1981. p. 128-9.

39. Defilipps RA, Maina SL, Pray LA. The Palauan and Yap medicinal plant studies of Masayoshi Okabe 1941-1943. Atoll Res Bull. 1988; 317:1-25. https://doi.org/10.5479/ si.00775630.317.1

40. Yamada T. A report on the ethnobotany of the Nyindu in the eastern part of the former Zaire. Afr Study Monogr. 1999; 20(1):1-72.

41. Ong HC, Nordiana M. Malay ethno-medico botany in Machang, Kelantan, Malaysia. Fitoterapia. 1999; 70:50213. https://doi.org/10.1016/S0367-326X(99)00077-5

42. Thomas T, Panikkar JB, Subramoniam A, Krishnan NM, Panikkar KR. Antitumour property and toxicity of Barringtonia racemosa Roxb seed extract in mice. J Ethnopharmacol. 2002; 82(2-3): 223-7. https://doi. org/10.1016/S0378-8741(02)00074-0

43. Biswas M, Roy DM, Rahman MM, Hossen M. Medicinal plants for snake bite and sexual dysfunction in Jessore and Bagerhat districts of Bangladesh. Int J Med Arom Plants. 2013; 3(4):486-91.
44. Powling A. Recording medicinal plants in an Indonesian village. Biodiversity Science. Issue no. 6; 2012. Available from: http://www.biodiversityscience.com/2012/04/26/ recording-medicinal-plants/

45. Jayaprasad B, Thamayandhi D, Sharavanan P. Traditionally using antidiabetic medicinal plants in Tamil Nadu. Int J Res Pharm Biosci. 2012; 2(1):1-8.

46. Chandran SMD, Ramachandra TV, Joshi NV, Prakash M, Mesta PN, Settur B, Mukri VD. Conservation and management of mangroves in Uttara Kannada, central western Ghats. Environmental Information System Technical Report. 2012; 50:1-160.

47. Razafindraibe $M$, Kuhlman AR, Rabarison $H$, Rokotoarimanana V. Rajeriarison C, Rakotoarivelo N, et al. Medicinal plants used by women from Agnalazaha littoral forest (Southeastern Madagascar). J Ethnobiol Ethnomed. 2013; 9:73. https://doi.org/10.1186/17464269-9-73 PMid:24188563 PMCid:PMC3827988

48. Kabir T, Saha S. A study on the indigenous medicinal plants and healing practices of Murong tribe in Khagrachari district (Bangladesh). Int J Pharmacogn. 2014; 1(10):6549.

49. Chander MP, Kartick C, Vijayachari P. Herbal medicine and healthcare practices among Nicobarese of Nancowry group of islands-an indigeneous tribe of Andaman and Nicobar islands. Indian J Med Res. 2015; 141:720-44. PMid:26139792 PMCid:PMC4510773

50. Neamsuvan O, Sengnon N, Seemaphrik N, Chouychoo M, Rungrat R, Bunrasri S. A survey of medicinal plants around upper Songkhla Lake, Thailand. Afr J Tradit Complement Altern Med.2015; 12(2):133-43. https://doi. org/10.4314/ajtcam.v12i2.20

51. Tholl D. Biosynthesis and biological functions of terpenoids in plants. Adv Biochem Eng Biotechnol. 2015; 148:63-106. https://doi.org/10.1007/10_2014_295

52. Grassman J. Terpenoids and plant antioxidants. Vitam Horm. 2005; 72:505-35. https://doi.org/10.1016/S00836729(05)72015-X

53. Makkar HPS, Siddhuraju P, Becker K. Methods in Molecular Biology: Plant Secondary Metabolites. Totowa, NJ, USA: Humana Press; 2007. p. 93-100. https://doi. org/10.1007/978-1-59745-425-4_16

54. Dubois MAL, Wagner H. Bioactive saponis from plants: An update. In: Rahman AU, editor. Studies in natural products chemistry volume 21 . Bioactive natural products (Part B). Amsterdam, Netherlands: Elsevier Science; 2000. p. 633.

55. Anantaraman R, Pillai KSM. Barringtogenol and barringtogenic acid, two new triterpenoid sapogenins. 
Ethnobotanical Profiles and Phytochemical Constituents of Barringtonia racemosa L. for Potential Scrutiny of Bioactive Compounds through Plant Biotechnology

J Chem Soc. 1956; 4369-73. https://doi.org/10.1039/ jr9560004369

56. Lin YT, Lo TB, Su SC. Triterpenoids. II Isolation of triterpenoid sapogenins from the fruits of Barringtonia racemosa Blume. J Chin Chem Soc. 1957; 4: 77-81. https://doi.org/10.1002/jccs.195700009

57. Yang Y, Deng Z, Proksch P, Lin W. Two new 18-en-oleane derivatives from marine mangrove plant, Barringtonia racemosa. Pharmazie. 2006; 61(4):365-66. https://doi. org/10.1002/chin.200630195

58. Hasan CM., Khan S, Jabbar A, Rashid MA. Nasimalun $\mathrm{A}$ and $\mathrm{B}$ : neo-clerodane diterpenoids from Barringtonia racemosa. J Nat Prod. 2000; 63:410-1. https://doi. org/10.1021/np9904881

59. Sun HY, Long LJ, Wu J. Chemical constituents of mangrove plant Barringtonia racemosa. Zhong Yao Cai. 2006; 29:671-2. PMid:17059003

60. Nurul-Mariam H, Radzali M, Johari R, Syahida A, Maziah M. Antioxidant activities of different aerial parts of putat (Barringtonia racemosa L.). Malays J Biochem Mol Biol. 2008; 16(2):15-9.

61. Patil KR, Patil CR, Jadhav RB, MahajanVK, Patil PR, Gaikwad PS. Anti-arthritic activity of bartogenic acid isolated from fruits of Barringtonia racemosa Roxb. (Lecythidaceae). Evid Based Complement Alternat Med. 2011; 8(1):1-7. https://doi.org/10.1093/ecam/nep148 PMid:19770265 PMCid:PMC3137566

62. Piironen, V, Lindsay DG, Miettinen TA, Toivo J, Lampi A-M. Plant sterols: Biosynthesis, biological function and their importance to human nutrition. J Sci Food Agric. 2000; 80:939-66. https://doi.org/10.1002/(SICI)10970010(20000515)80:7<939::AID-JSFA644>3.3.CO;2-3

63. Wang K, Senthil-Kumar M, Ryu CM, Kang L, Mysore KS. Phytosterols play a key role in plant innate immunity against bacterial pathogens by regulating nutrient efflux into the apoplast. Plant Physiol. 2012; 158(4):1789-802. https://doi.org/10.1104/pp.111.189217 PMid:22298683 PMCid:PMC3320186

64. Dufourc EJ. The role of phytosterols in plant adaptation to temperature. Plant Signal Behav. 2008; 3(2):133-4. https://doi.org/10.4161/psb.3.2.5051 PMid:19704733 PMCid:PMC2634003

65. Dai J, Mumper RJ. Plant phenolics: Extraction, analysis and their antioxidant and anticancer properties. Molecules. 2010; 15:7313-52. https://doi.org/10.3390/ molecules15107313 PMid:20966876

66. Ahmad R, Abdullah N. Antioxidant principles and in vitro evaluation methods. Selangor, Malaysia: UiTM Press; 2013.

67. Amran N, Rani ANA, Mahmud R, Khoo BY. Antioxidant and cytotoxic effect of Barringtonia racemosa and Hibiscus sabdariffa in MCF-7 human breast cancer cell line. Pharmacognosy Res. 2016; 8(1):66-70. https:// doi.org/10.4103/0974-8490.171104 PMid:26941539 PMCid:PMC4753763

68. Kabera JN, Semana E, Mussa AR, He X. Plant secondary metabolites: Biosynthesis, classification, function and pharmacological properties. J Pharm Pharmacol. 2014; 2014:377-92.

69. Sarkar A. Plant stem cells. New Delhi: Discovery Publishing House; 2009.

70. Govinden-Soulange J, Boodia N, Dussooa C, Gunowa R, Deensah S, Facknath S, et al. Vegetative propagation and tissue culture regeneration of Hibiscus sabdariffa $\mathrm{L}$. (Roselle). World J Agric Sci. 2009; 5(5):651-61. 